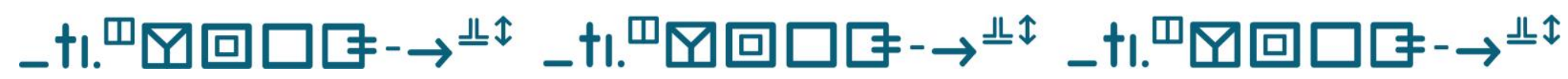

\section{Injustiças sociais e direitos humanos nas literaturas surdas: olhares emergentes para saberes poéticos}

\section{Social injustices and human rights in deaf literature: emerging views for poetic knowledge}

(iD Jonatas Rodrigues Medeiros

Universidade Federal de Santa Catarina, Florianópolis, Santa Catarina, Brasil Universidade Federal do Paraná, Curitiba, Paraná, Brasil jonataslibras@gmail.com

iD 9

Silvana Aguiar dos Santos

Universidade Federal de Santa Catarina, Florianópolis, Santa Catarina, Brasil s.santos@ufsc.br

iD 9

Gabriela Grigolom Silva

Universidade Estadual do Paraná, Curitiba, Paraná, Brasil gabrielasofiantonio1@gmail.com

iD 9

Edvaldo Carmo dos Santos

Universidade Paulista, São Paulo, São Paulo, Brasil edinhopoesia@gmail.com

Resumo: O objetivo deste artigo foi mapear como as poesias surdas abordam a temática de injustiça social e direitos humanos, pois é crescente a circulação das poesias sinalizadas em vários formatos e suportes, tais como saraus, slams, festivais e congressos ou, ainda, em espaços virtuais, como plataformas de vídeos e redes sociais. O recorte concentrou-se na coleta de dados de poesias disponíveis em ciberespaços: corpus de slams, videopoesia e saraus em Libras registrados em vídeo. Duas poesias são analisadas e cotejadas com autores de perspectivas pós-coloniais e articulações possíveis para o campo das Literaturas Surdas. Os resultados apontam que as injustiças sociais e o 


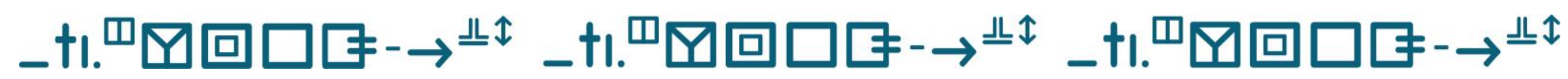

tensionamento dos direitos humanos são temáticas cruciais apresentadas nas poesias analisadas em Libras, que operam como denúncia da privação linguística das comunidades surdas, violência racial e de gênero, privação de acesso a direitos básicos em serviços públicos, dores causadas por padrões estéticos e luta pelos direitos LGBTQI+.

Palavras-chave: Injustiças Sociais; Direitos Humanos; Literaturas Surdas.

Abstract: The purpose of this article was to map how deaf poetry addresses the theme of social injustice and human rights, as there is an increasing circulation of signed poetry in various formats and supports, such as soirees, slams, festivals and congresses, or even in spaces such as video platforms and social networks. The focus was on the collection of poetry data available in cyberspace such as: corpus of slams, videopoetry and soirees in Brazilian Sign Language recorded on video. Two poems are analyzed and compared with authors from post-colonial perspectives and with possible articulations for the field of Deaf Literature. The results show that social injustices and the tensioning of human rights are crucial themes presented in the poems analyzed in Brazilian Sign Language, which operate as a denunciation of the linguistic deprivation of deaf communities, racial and gender violence, deprivation of access to basic rights in public services, pain caused by aesthetic standards and the fight for LGBTQI+ rights.

Keywords: Social Injustice; Human rights; Deaf Literature.

Submetido em 29 de abril de 2021.

Aceito em 23 de maio de 2021.

Publicado em 14 de dezembro de 2021. 


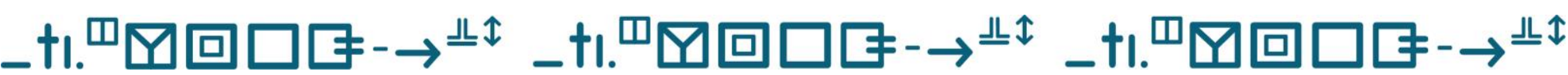

Injustiças sociais e direitos humanos nas literaturas surdas: olhares emergentes para saberes poéticos

Jonatas Rodrigues Medeiros • Silvana Aguiar dos Santos et al.

\section{Introdução}

No campo dos Estudos Surdos ou mesmo dos Estudos sobre Língua Brasileira de Sinais (Libras), produções acadêmicas (teses, dissertações, artigos, capítulos de livros e outros) que articulam as Literaturas Surdas e suas diferentes manifestações artísticas com os Direitos Humanos constituem-se como temáticas emergentes. Dessa forma, interrogar como as poesias em línguas de sinais manifestam a pauta dos direitos humanos torna-se relevante. A partir dessa asserção, propomos, neste trabalho, apresentar um mapeamento inicial de poesias e poetas que articulam a temática de injustiças sociais e de direitos humanos dentro das Literaturas Surdas.

Dessa forma, este trabalho busca descrever como as poesias surdas abordam a temática dos direitos humanos e das injustiças sociais, tomando como ponto de análise três poemas selecionados, cujos marcadores versam sobre opressões, violência racial e de gênero, privação de acesso a direitos básicos em serviços públicos, dores causadas por padrões estéticos e a luta pelos direitos LGBTQI+. Não somente as temáticas dessa natureza têm sido emergentes nas línguas de sinais como também os vários formatos e suportes em que essas poesias sinalizadas circulam em nossa sociedade. É possível observarmos a circulação de poesias realizadas por pessoas surdas em diversos espaços físicos, tais como saraus, slams ${ }^{1}$, festivais e congressos

\footnotetext{
${ }^{1}$ No Brasil, os Slams são espaços de luta e resistência, em que poetas, por meio de suas poesias faladas/sinalizadas, produzem discursos políticos, permitindo uma reflexão nos participantes sobre seu papel na sociedade (SANTOS; GRIGOLOM; MEDEIROS, 2020).
} 


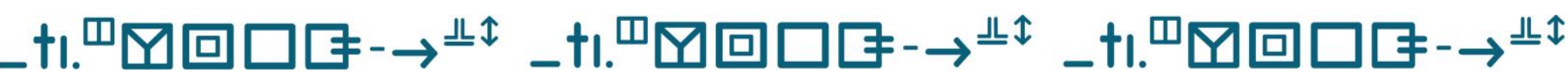

Injustiças sociais e direitos humanos nas literaturas surdas: olhares emergentes para saberes poéticos

Jonatas Rodrigues Medeiros • Silvana Aguiar dos Santos et al.

língua de sinais e debates interseccionais ${ }^{2}$. Nessa perspectiva, um conjunto de autores, tais como Hooks (2019a, 2019b), Kilomba (2019), Fernandes e Moreira (2017), Beer (2016), Ladd (2013), Rezende (2012), Brito (2012), Santos (2019), Sutton-Spence $(2006,2014,2018,2020)$ e Quadros e Sutton-Spence (2006), respalda a presente discussão, mostrando-nos como a articulação injustiças sociais e direitos humanos pode ser produtiva para analisar e refletir as Literaturas Surdas.

Diante dessas considerações iniciais, este texto encontra-se organizado nas seguintes seções. Na introdução, contextualizamos as principais discussões, indagações e explicamos as motivações que contribuíram para a emergência dessas reflexões. Na segunda seção, descrevemos as Literaturas Surdas e seus sentidos, bem como situamos os principais autores e suas contribuições que dialogam diretamente com essa temática. Na terceira seção, recuperamos as principais reflexões que articulam Literatura e Direitos Humanos, no intuito de problematizarmos os conceitos de humanos, universal e direitos. Na quarta seção, descrevemos os principais elementos que constituem as injustiças sociais e os direitos humanos nas Literaturas Surdas. Para isso, apresentamos três poesias surdas que exemplificam as interseccionalidades, a saber: mulheres negras surdas, violências LGBTQI+ e violência estética, além da poesia da quebrada. Por fim, nas reflexões finais, resgatamos as ideias principais discutidas no

\footnotetext{
2 Santos, Grigolom e Medeiros (2020, p. 34) colocam que “[...] a interseccionalidade ganhará destaque acadêmico a partir da década de 1980, com a pesquisadora e ativista negra Kimberlé Crenshaw, que irá cunhar o conceito. Em sua tese, a autora defende que, além do gênero, existem outras identidades que perpassam as mulheres negras e precisam ser levadas em conta, como raça e classe. Este conceito vem sendo utilizado nas pesquisas acadêmicas que abordam em suas discussões raça, gênero e classe".
} 


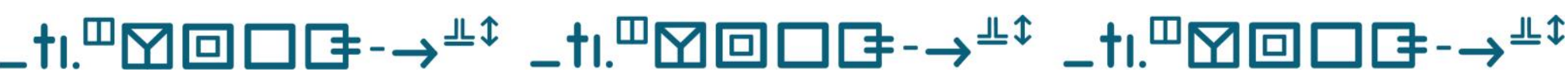

Injustiças sociais e direitos humanos nas literaturas surdas: olhares emergentes para saberes poéticos

Jonatas Rodrigues Medeiros • Silvana Aguiar dos Santos et al.

texto, além de sugerirmos temáticas que podem interessar futuras pesquisas.

\section{Literaturas Surdas e seus sentidos}

Antes de adentrarmos o campo das Literaturas Surdas e dos direitos humanos, faz-se necessário indagarmos: Quais sentidos e funções as Literaturas Surdas assumem em diferentes contextos sociais e políticos? Sim, Literaturas no plural ${ }^{3}$, a fim de ratificar as múltiplas possibilidades de manifestação artísticas, sejam elas em espaços físicos, tais como saraus, slams, festivais e congressos ou, ainda, em espaços virtuais como plataformas de vídeos e redes sociais. Tal visibilidade social e acadêmica da Libras acentuou-se ainda mais diante do cenário das políticas públicas nacionais, o qual promoveu reconhecimento da diferença linguística e cultural da cidadania bilíngue da população surda brasileira. Sutton-Spence (2020, p. 2), ao debater a interface entre direitos linguísticos e Literatura Surda, afirma que “[...] o conhecimento do mundo surdo só se dá através do acesso ao conhecimento compartilhado da literatura, da cultura e da história das comunidades surdas, que é passado de uma geração à outra" porém, mesmo dada tal constatação "[...] a maior parte das políticas linguísticas e educacionais não apoiam a literatura de língua de sinais" (SUTTON-SPENCE, 2020, p. 3).

\footnotetext{
${ }^{3}$ Neste trabalho, o conceito de Literaturas Surdas será utilizado no plural, por entender que ele abarca diferentes formatos e registros das manifestações artísticas e literárias, assim como das comunidades que emergem. Afinal, não há apenas uma comunidade surda; assim, não haveria também uma única literatura surda. Desse modo, consideramos relevante que o conceito de Literaturas Surdas possa incluir diversos tipos de literaturas, a saber: literatura surda LGBTQI+, literatura negra surda, literatura de mulheres surdas, e assim sucessivamente. Essas literaturas baseiam-se em temáticas que valorizam as línguas de sinais e os diferentes modos de ser surdos.
} 


\section{_t..}

Injustiças sociais e direitos humanos nas literaturas surdas: olhares emergentes para saberes poéticos

Jonatas Rodrigues Medeiros • Silvana Aguiar dos Santos et al.

A positivação do direito à Libras como língua de instrução e expressão das comunidades surdas foi um marco importante não somente pelo reconhecimento legal, mas também pelos desdobramentos respaldados no Decreto n. 5.626, de 22 de dezembro de 2005 (BRASIL, 2005). A educação bilíngue é um desses exemplos que mostram as reivindicações das comunidades surdas. Fernandes e Moreira (2017) explicam que constantes tensionamentos e negociações com o Estado, realizados pelos movimentos surdos, têm como principal bandeira a reivindicação da educação bilíngue para surdos, compreendendo o direito de serem educados em Libras como primeira língua.

Ainda nesta pauta do reconhecimento linguístico, o direito de produzir suas literaturas surdas nas múltiplas formas de expressão, seja no espaço escolar, seja fora dele, é uma temática que merece ser problematizada. Dito de outro modo, as Literaturas Surdas assumem sentidos e funções políticas, sociais importantes e que merecem ser discutidas à luz das narrativas que enaltecem os sujeitos surdos. De acordo com Quadros e Sutton-Spence (2006), a literatura sinalizada emerge como forte marcador cultural das comunidades surdas, salientando o fortalecimento da comunidade linguística, do orgulho surdo e do empoderamento dos povos surdos a partir da poesia sinalizada.

Nessa perspectiva, os povos surdos apresentam suas culturas e seus artefatos culturais ao longo da história, resistindo e produzindo contranarrativas, as quais confrontam as metanarrativas pautadas na estrutura ouvintista. Justamente nesse viés, os movimentos surdos 


\section{_t..}

Injustiças sociais e direitos humanos nas literaturas surdas: olhares emergentes para saberes poéticos

Jonatas Rodrigues Medeiros • Silvana Aguiar dos Santos et al.

denunciam as metanarrativas clínico-terapêuticas ${ }^{4}$ (LANE, 1992; SKLIAR, 1999, 2013; REZENDE, 2012; FERNANDES, 2011; TERCEIRO, 2018), dirigindose à perspectiva socioantropológica que contempla as formas surdas de viver, a língua de sinais, as culturas surdas e as identidades surdas.

Essas metanarrativas foram impostas desde a modernidade e funcionaram como "verdades", contribuindo diretamente na subjugação dos corpos surdos em detrimento do "corpo ideal", romantizado na insurgência da modernidade e das filosofias iluministas do Século XVIII. Para Oto (2017), a "[...] colonialidade é constitutiva das formas sociais históricas da modernidade" e, para esta análise, é necessário compreendermos a sua matriz de poder de larga duração que "[...] se estrutura na tripla relação entre sexo (gênero), raça e classe" (OTO, 2017, p. 15).

Desse modo, rompendo com as amarras colonizadoras sobre discursos impostos e tidos como verdade em função da estrutura ouvinte, as literaturas surdas sinalizadas resgatam o valor das línguas de sinais e das culturas surdas. A contranarrativa do discurso colonizador sobre os corpos surdos e a própria alteridade surda são narradas por ativistas e pesquisadores surdos, bem como aliados não surdos, cujos movimentos e insurgências embasam a emergência do campo dos Estudos Surdos.

Do nosso ponto de vista, respaldados nas contribuições de Ladd (2013), pode-se dizer que tais literaturas surdas caracterizam-se pela busca do Deafhood (surdidade). Para Terceiro (2018), o conceito de Deafhood (surdidade) pode ser entendido como uma jornada coletiva do povo surdo ou, então, “[...] um processo que possibilita a descolonização do corpo Surdo,

\footnotetext{
${ }^{4}$ Fernandes (2011) enquadra o objetivo da medicina em corrigir a "anormalidade" surda pelo viés da cura, em diálogo com Sánchez, a autora denomina esse período como "medicalização da surdez" como método de evitar a manifestação das diferenças.
} 


\section{_t..}

Injustiças sociais e direitos humanos nas literaturas surdas: olhares emergentes para saberes poéticos

Jonatas Rodrigues Medeiros • Silvana Aguiar dos Santos et al.

permitindo a tomada de consciência do longo [...] processo histórico de opressão e colonização que muitos Surdos viveram e a descoberta de uma nova identidade cultural" (TERCEIRO, 2018, p. 47).

As Literaturas Surdas desempenham também funções políticas e reconfiguram modos de ser e de expressar em diferentes momentos históricos, quando tais expressões buscam o conceito de Deafhood (surdidade), a reivindicação dos direitos linguísticos e o acesso aos bens e consumos na própria língua ou, ainda, o direito de existir como sujeito. Pesquisadores como Mourão (2011, 2016), Nakagawa (2012) e Sutton-Spence (2014) corroboram essa premissa das temáticas desenvolvidas pelas comunidades surdas.

Mourão (2011, p. 50) afirma que "[...] a literatura surda traz histórias de comunidades surdas, com os processos sociais e as práticas discursivas relacionadas que circularam em diferentes lugares e em diferentes tempos". Em síntese, o autor aponta a potência que as Literaturas Surdas apresentam, na medida em que elas promovem as traduções culturais surdas. Nessas traduções, são compartilhados também conhecimentos acumulados cultural e linguisticamente, abrindo possibilidades e espaços para as potências surdas e suas criações, críticas literárias e empoderamentos surdos. As contribuições de Mourão (2016, p. 229) apontam que a “[...] Literatura Surda se transforma em uma bandeira nos processos políticos e de luta por uma educação bilíngue", isso devido ao processo em que "[...] os sujeitos surdos percebem e reconhecem a existência de artes surdas e mãos literárias" (MOURÃO, 2016, p. 229).

Ainda na perspectiva do empoderamento das comunidades surdas e o reconhecimento de seus temas como produção histórica, cultural e socialmente contextualizada, pode-se perceber os constructos chaves para 


\section{_t..}

Injustiças sociais e direitos humanos nas literaturas surdas: olhares emergentes para saberes poéticos

Jonatas Rodrigues Medeiros • Silvana Aguiar dos Santos et al.

um letramento social e crítico. De acordo com Sutton-Spence (2014, p. 113), "[...] a poesia em língua de sinais é inseparavelmente unida ao mesmo fenômeno, constitutivo da identidade Surda, conhecimento e poder surdo". Dito de outro modo, esses elementos apresentados por Sutton-Spence (2014) podem caracterizar as Literaturas Surdas como forte instrumento de letramento crítico e linguístico das comunidades surdas, fortalecendo seu caráter comunitário, seu sentimento de pertença e sua aceitação. Essa noção de pertença dialoga diretamente com as contribuições de Karnopp (2006), pois a autora explica e observa o caminho de autorrepresentação dos grupos surdos em suas literaturas, seja em narrativas, seja em adaptações. Em suma, na visão da autora, essas Literaturas Surdas são marcadas pela experiência de suas existências.

Se as literaturas surdas assumem, portanto, sentidos e funções diversas, por que não articular esse campo com discussões e temáticas que colocam em cena a pauta dos direitos humanos? Esse convite à reflexão é um dos primeiros passos na construção das respostas possíveis para a pergunta estabelecida neste texto, a saber: Como a poesia em língua de sinais manifesta a pauta das injustiças sociais e dos direitos humanos? Em um primeiro momento, parece-nos que as poesias que versam sobre injustiças sociais e os direitos humanos são produzidas nas literaturas surdas, porém com pouca visibilidade. Na próxima seção, é o que colocamos em diálogo, em busca de compreender os principais elementos constituintes dessa articulação: literatura e direitos humanos.

\section{Literatura e direitos humanos: universal, humanos e direitos}




\section{_t..}

Injustiças sociais e direitos humanos nas literaturas surdas: olhares emergentes para saberes poéticos

Jonatas Rodrigues Medeiros • Silvana Aguiar dos Santos et al.

A articulação entre literatura e direitos humanos parece-nos recente, pois as pautas que interessam essa aproximação raramente são incluídas no cânone. A literatura canônica que se propõe universal sempre foi operada por uma classe dominante do poder político-econômico - sequer universal, pois escamoteia o desejo hegemônico eurocêntrico de fazer sua imagem. Fanon (2008), em Pele negra, máscaras brancas, analisa o desejo de o homem branco se fazer universal, pois não anuncia sua condição racial. BernardinoCosta (2016) comenta que, para Fanon, o corpo branco se esconde no véu do universalismo para engendrar sua política de construir "[...] o mito do conhecimento sem ponto de vista, desinteressado" (BERNARDINO-COSTA, 2016, p. 517).

Nessa linha, os séculos XVIII e XIX marcaram a invenção da instituição literária, a partir de diferentes conceitos que foram formulados sobre ela e seus usos. Os séculos XIX e XX colocaram a literatura dentro de um pensamento salvacionista de uma possível emancipação da humanidade uma literatura a serviço da pátria e da consolidação do nacionalismo, servindo, assim, para diversas ideologias e manifestações de poder. Eagleton (2006) explica que os discursos acadêmicos seguem diferentes abordagens desde formalistas-estruturalistas, preocupados com a forma literária e os usos especiais da linguagem a abordagens relacionais observando a produção literária em seu contexto.

Souza (2006) aponta um panorama de epistemologias dos Estudos Literários recorrendo às diversas escolas e pensadores que se encarregaram de produzir discursos acadêmicos científicos sobre o que seria a literatura, seus usos e as possíveis formas de abordá-la. A pesquisadora retoma, por exemplo, autores como Antoine Compagnon, o qual afirma a literatura como uma área que carrega em si um cogito literário universal. Essa linha de 


\section{_t..}

Injustiças sociais e direitos humanos nas literaturas surdas: olhares emergentes para saberes poéticos

Jonatas Rodrigues Medeiros • Silvana Aguiar dos Santos et al.

pensamento busca o que há de comum em toda literatura e o estabelecimento do seu cânone, correlacionado aos princípios humanistas de base iluministas, discursa sobre uma pretensa literatura universal, podendo responder sobre o valor literário ou o que é ou não literatura.

Eagleton (2006) aponta o termo "valor", que pode ser dado à literatura, como transitivo, pois o que é valioso pode mudar a depender dos contextos e das pessoas em determinados objetivos, tornando completamente instável a classificação do que é literatura. Partindo desse viés que discute a perspectiva universal na literatura, como propor outros caminhos para pensar e ampliar os horizontes da literatura? Nessa perspectiva, a relação de literatura e direitos humanos é apresentada por Dalcastagnè, Dutra e Frederico (2018, p. 9) como possibilidade de "ampliação do imaginário estético e político" na prática de representação da presença ou falta dos direitos humanos, tornando a literatura "um espaço de interlocução e um abrigo".

Assim sendo, problematizar o conceito de direitos humanos é de suma importância, especialmente aquela perspectiva baseada no humanismo europeu de tradição iluminista, a qual se constitui como superior a partir da racialização do pensamento, da civilização e da linguagem. Carneiro (2005) afirma que tal perspectiva dos direitos humanos importava alguns debates trazidos de Hegel e explica que essa linha de pensamento tratava, por exemplo, de pessoas negras como ontologicamente diferentes, portanto desprovidas de humanidade.

Mbembe (2019, p. 30) comenta que o escritor da obra Razão da História “[...] dizia a propósito de tais figuras que eram estátuas sem linguagem nem consciência de si". Piza (2019, p. 187) expõe que, para Mbembe, "[...] tal 


\section{_t..}

Injustiças sociais e direitos humanos nas literaturas surdas: olhares emergentes para saberes poéticos

Jonatas Rodrigues Medeiros • Silvana Aguiar dos Santos et al.

Ainda nessa linha, Mbembe (2019) descreve que, na França humanista, a designação racial foi tratada pela violência do não mostrar, "pela recusa em ver" o negro como sujeito parte da humanidade e do universal. Assim, agiase com práticas de encobrimento, desfiguração e travestimento, as quais foram articuladas por instâncias privilegiadas como "a literatura, a pintura e a dança" (MBEMBE, 2019, p. 127). Para Mbembe (2019), o universal é um projeto encontrado na colonização, como herdeira do lluminismo e a deriva de um suposto governo da razão universal. "A razão universal supõe a existência de um sujeito homônimo" (MBEMBE, 2019, p. 174).

Na mesma linha, Fanon (2008) nega-se a recorrer ao conceito de universal. Para Hall (2018, p. 96), “o universal é um signo vazio”. Já Kilomba (2019, p. 90) posiciona que sua preocupação é com “[...] a produção de subjetividade e não com a produção de conhecimento universal"; desse modo, Kilomba quer espaços para novas linguagens e formas de discursos. Assim sendo, diante de todos os argumentos já explicitados no presente trabalho, a categoria "universal" e, por consequência, a literatura universal não são compartilhadas neste texto.

Ao trazermos o conceito de direitos humanos, buscamos sua ressignificação a partir da crítica da modernidade e da colonialidade, uma vez que as inspirações para os direitos humanos são em lógicas universais. Nessa linha, Baldi (2015, p. 49) leva-nos a repensar os direitos humanos em chave descolonial, permitindo "[...] a abertura a outros saberes, que tinham sido silenciados, oprimidos, ocultados ou tidos como inexistentes".

Posto isso, qual literatura estamos propondo como respaldo teórico dessa reflexão? Brito (2012), ao analisar o pensamento de Lélia Gonzalez, afirma que os discursos racializados produzidos e legitimados pelas ciências sociais, políticas, historiográficas e biológicas, também são presentes na “[...] 


\section{_t..}

Injustiças sociais e direitos humanos nas literaturas surdas: olhares emergentes para saberes poéticos

Jonatas Rodrigues Medeiros • Silvana Aguiar dos Santos et al.

alta literatura, clássica; canônica, que reivindica para si o intocável lugar instituído por uma Tradição e, portanto, detentora de prestígio" (BRITO, 2012, p. 37).

Brito (2014) observa que "efeitos violentos, produzidos pela articulação do racismo e sexismo sobre a mulher negra, é a força motriz da produção intelectual de Lélia Gonzalez" (BRITO, 2014, p. 21). Conforme ainda explica Brito (2014), Gonzales já produzia, nos anos de 1980, uma discussão pós-colonial que denunciava violências sofridas pela intersecção entre raça, gênero e classe. Além disso, realizava uma crítica ao pensamento acadêmico eurocêntrico e à herança etnocêntrica, que para ela causava uma miopia epistêmica que negligenciava "a contribuição indígena e africana na história do Brasil" (BRITO, 2014, p. 29).

Kilomba (2019, p. 91) demarca que a teoria pós-colonial "oferece o enquadramento apropriado para a análise de políticas de raça e gênero, [...] e estratégias políticas de descolonização". Assim, a articulação entre literatura e direitos humanos opõe-se ao desenho do que se propõe como "universal", pois, conforme Santana (2014), ela compreende um compromisso com a desconstrução do racismo e do patriarcado, já que se identifica "como um contradiscurso literário e histórico" que se "apresenta como ação político ideológica que se interpõe ao cânone e faz emergir um discurso histórico Outro" (SANTANA, 2014, p. 157). Ao passo que se propõe como ferramenta política, para Santana (2014), desloca-se a centralidade da "construção de uma historiografia hegemônica, masculina, burguesa e eurocêntrica" para, então, "atribuir valor aos sujeitos excluídos, dando-Ihes voz e autorizando os sujeitos enunciadores da própria história, que desafia e desestabiliza a oficial" (SANTANA, 2014, p. 158). 


\section{_t..}

Injustiças sociais e direitos humanos nas literaturas surdas: olhares emergentes para saberes poéticos

Jonatas Rodrigues Medeiros • Silvana Aguiar dos Santos et al.

Delgado (2018, p. 31), ao analisar o Guia afetivo da periferia, de Marcus Faustini, identifica sua força literarizante e sua "criatividade na vivência subjetiva cotidiana", que coloca em enquadramento os cenários sociais de desigualdades e o sonho de ascensão. A obra é reconhecida por Delgado (2018) como um livro de formação social que exerce sua criatividade narrativa, considerando uma narrativa com base no denuncismo social. E o que a literatura tem a ver com essas questões?

Cardoso e Silva (2017) e Silva e Cardoso (2018) afirmam que a literatura pode ser vista como "[...] uma ferramenta para investigar e propagar princípios de determinados grupos $[. .$.$] ", isso porque ela "[...] revela$ características locais, externando as peculiaridades e a realidade social e determinando período da história ou problemas sociais latentes" (CARDOSO; SILVA, 2017, p. 61). Isso pode ser observado na representação da violência no conto Ana Davenga, de Conceição Evaristo, o qual retrata a condição feminina negra em contexto de exclusão social e racial.

Da rememoração da dor e das suas vivências, a escritora Afromineira, Conceição Evaristo, produz uma literatura de escrevivência, método cunhado pela autora. Para Souza (2018), é como uma ação coletiva da enunciação dos subalternos na literatura, como uma agência que articula a vivência com a militância. Ainda, Souza e Coronel (2018, p. 2) explicam que "a noção de escrevivência se aproxima do conceito de testemunho proposto por Ginzburg", que vincula, no texto, a "vivência de um grupo de vítimas, das quais o autor do texto é articulador" (SOUZA; CORONEL, 2018, p. 2).

Para Oliveira (2009, p. 622), "nota-se o que a autora [Conceição Evaristo] chama de escrevivência, a escrita de um corpo, de uma condição, de uma experiência negra no Brasil". Assim, podemos observar que a literatura que retrata discursos sobre a ausência de direitos humanos se 


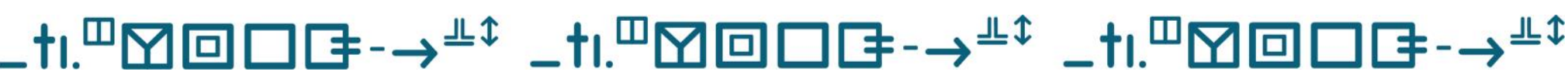

Injustiças sociais e direitos humanos nas literaturas surdas: olhares emergentes para saberes poéticos

Jonatas Rodrigues Medeiros • Silvana Aguiar dos Santos et al.

relaciona com narrativas periféricas, visando a valoração das condições de produção de autores que estão marginalizados devido aos seus territórios, às suas temáticas e condições sociais de produção literária, tudo sustentado pelo racismo estrutural ${ }^{5}$ à brasileira. Para Pereira (2016, p. 39), na literatura de Conceição Evaristo, podemos encontrar uma narrativa periférica que retrata "não apenas as condições sociais, mas também as econômicas e culturais consistem em relações vulneráveis, atravessadas por questões étnico-raciais, de gênero e de classe social".

Os sujeitos que protagonizam as histórias, assim como aqueles que a escrevem e inscrevem ${ }^{6}$ são confundidos entre viventes testemunhais, personagens reais ou ficções-factuais. São representantes e representados por histórias que atravessam um todo da experiência coletiva. Palmeira e Souza (2008, n.p.), ao comentarem sobre representação de gênero e afrodescendência na literatura de Conceição Evaristo, evidenciam a importância da construção de uma representação participativa, pois, "como sabemos por experiência própria, a representação tem um forte poder de perpetuar-se e influenciar a vida social dos grupos objetos da representação" (PALMEIRA; SOUZA, 2008, n.p.).

A literatura periférica pode ser descrita como literatura testemunhal (CEI, 2011), manifesto e voz dos que vivem à margem da sociedade, e literatura de territórios (DAMASCENA, 2015) ou a quebra com a estigmatização de grupos minorizados (CARNEIRO, 2017). Como literatura

\footnotetext{
${ }^{5}$ Levando em consideração o debate de Munanga (2019) sobre como o racismo no Brasil foi escamoteado pelos discursos de democracia racial e mestiçagem social e uma etnia nacional brasileira que acolhe gente variada, apagando as marcas de violência de "uma ideologia hegemônica baseada no ideal de branqueamento". (MUNANGA, 2019, p. 95).

${ }^{6}$ Inscrever como registro e memória, reconhecendo tanto as literaturas não escritas quanto as literaturas orais, manifestações corporais, registradas em vídeos ou aquelas produzidas com outros elementos culturais, como a culinária, a música, a dança e a religiosidade.
} 


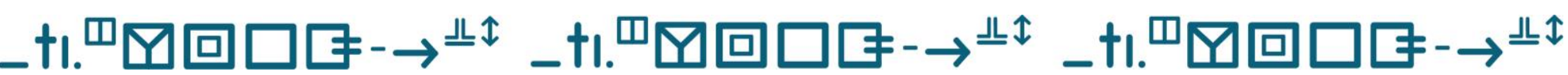

Injustiças sociais e direitos humanos nas literaturas surdas: olhares emergentes para saberes poéticos

Jonatas Rodrigues Medeiros • Silvana Aguiar dos Santos et al.

subalternizada e menor, Souza (2018) a identifica como máquina revolucionária. Ao retratar sobre as dores da memória de guerra na literatura, Dalcastagnè (2018, p. 181) corrobora sobre a necessidade de transformar o esquecimento do sofrimento em narrativa, sobre "trazer de volta a dor do vivido".

O esquecimento opera a favor do silêncio, da tortura, da dor e da colonização. Césaire (2020, p. 38), ao citar a voz de opressão, ressoa as palavras: "façam a máquina de esquecimento funcionar!". Para Hooks (2019a, p. 38-39), essa "transição do silêncio à fala é, para o oprimido, o colonizado, o explorado, e para aqueles que se levantam e lutam lado a lado, um gesto de desafio que cura, que possibilita uma vida nova e um novo crescimento". Ginzburg (2008, p. 2) coloca que "o problema da busca dos direitos humanos não se dissocia da dificuldade de enunciação dos mesmos".

Em Fanon (2008, p. 33), "falar é existir absolutamente para o outro" e é tão somente "[...] através de uma tentativa da retomada de si e de despojamento, e pela tensão permanente de sua liberdade [...]" que podemos "[...] criar as condições de existência ideais em um mundo humano (FANON, 2008, p. 191). Na cadência da resistência, Jesus e Souza (2020, p. 348) afirmam que "tomar a palavra para si é, antes de tudo, um ato revolucionário".

Hall (2006, 2018), nos Estudos Culturais, demanda grande peso à linguagem e às suas múltiplas possibilidades, uma vez que expõe que "a linguagem é o meio por excelência através do qual as coisas são representadas no pensamento, sendo, portanto, o meio no qual a ideologia é gerada e transformada" (HALL, 2018, p. 309). 


\section{_t..}

Injustiças sociais e direitos humanos nas literaturas surdas: olhares emergentes para saberes poéticos

Jonatas Rodrigues Medeiros • Silvana Aguiar dos Santos et al.

Hooks (2019a) ainda observa a experiência literária do pensamento e da escrita como "autorrecuperação" e que esse processo "constitui um modelo libertário para a mudança social, uma estratégia de resistência que deve ser compartilhada, sobre a qual se deve falar" (HOOKS, 2019a, p. 79).

Souza (2018) aproxima as narrativas subalternas da literatura como literatura menor (em uma lente deleuziana), contraponto da literatura hegemônica, que reconhece o caráter de "agenciamento coletivo de enunciação" e de discursos com "função de representatividade coletiva". Hooks (2019a, p. 44) observa que a poesia negra é composta de vozes múltiplas, não "unilaterais, monológicas ou estáticas, mas multidimensionais".

Um dos expoentes do gênero literário que congrega uma diversidade de poetas que usam da literatura como estratégia de mudança social é o Slam. Jesus e Souza (2020) expõem que esse movimento literário, em ascensão em todo o país - os slams -, "se tornaram um espaço importante para a expressão de mulheres, homens, garotos e garotas da periferia, sobretudo negras e negros, ligados à literatura marginal contemporânea" (JESUS; SOUZA, 2020, p. 337). Dessa forma, a relação literatura e direitos humanos manifesta-se em diferentes temáticas, tal como Lehnen (2018) aborda "direito à memória e à verdade", "direito de ter direitos", "direito à cidade", "direito a expressar a diferença sexual" ou "direito de retratar a diferença étnica" (LEHNEN, 2018, p. 15). Para a autora, na literatura brasileira contemporânea, há textos literários que "reivindicam direitos, outros que destacam as deficiências do modelo democrático brasileiro", o que sugere uma "democracia disjuntiva" (LEHNEN, 2018, p. 15). Ginzburg (2008, p. 11) alerta que, "em larga medida, o problema das relações entre literatura e 


\section{_t..}

Injustiças sociais e direitos humanos nas literaturas surdas: olhares emergentes para saberes poéticos

Jonatas Rodrigues Medeiros • Silvana Aguiar dos Santos et al.

direitos humanos tem ligação com omissões, lacunas e silenciamentos em discursos institucionais, jurídicos e científicos" (GINZBURG, 2008, p. 11).

Assim, observamos que a relação entre literatura e direitos humanos abarca uma gama de temáticas que tensionam o lugar de grupos que são minorizados e utilizam da literatura como ferramenta de denúncias sociais. O silenciamento, constituído como um processo da colonização, é revertido em voz-ativa, poema, escrita e inscrição; memória coletiva é combustível de produção; a vivência é método para a narrativa e as vozes são múltiplas e interseccionais.

Por fim, na literatura que dialoga com os direitos humanos, é possível verificarmos a diversidade de estratégias e de recursos empregados para a disseminação do conteúdo poético. Não só a literatura escrita, mas performática e no suporte vídeo também são utilizadas, produzindo literatura eletrônica como videopoesia e vídeo narrativa (FERREIRA, 2004; QUEIROZ, 2018). Para Ferreira (2004, p. 41): “A junção ou justaposição de signos verbais com visuais (e inclusive sonoros) é uma ruptura marco, pois significa uma desterritorialização ao propor uma visão mais ampla de arte e literatura".

\section{Injustiças sociais e direitos humanos nas literaturas surdas}

Nesta sessão, apresentamos o cenário das relações entre Literatura Surda e direitos humanos, a partir da descrição de algumas temáticas evocadas por alguns poetas surdos, que promovem suas agências no ciberespaço por meio das redes sociais. O crescimento dos movimentos sociais de direitos humanos no Brasil está diretamente articulado ao 


\section{-†ı.}

Injustiças sociais e direitos humanos nas literaturas surdas: olhares emergentes para saberes poéticos

Jonatas Rodrigues Medeiros • Silvana Aguiar dos Santos et al.

desenvolvimento das condições de expressão de grupos interessados em transformações e reivindicações de suas existências. Esses movimentos evidenciam que as diferenças estão na base dos problemas pautados em conflitos sociais. As comunidades surdas, como parte dos grupos minorizados, têm se desdobrado em diversos segmentos, fazendo-se presente e ocupando espaços de representação, nas esferas políticas, artísticas e acadêmicas.

No Brasil, no que tange às comunidades surdas, no campo dos direitos linguísticos como direitos humanos ou ainda direitos humanos linguísticos, destacam-se as pesquisas de Beer (2016) e Rodrigues e Beer (2016). Beer (2016) mostra-nos, por exemplo, sobre a ascensão dos direitos linguísticos à categoria de direitos humanos. A autora explica que os direitos linguísticos são parte do direito fundamental básico e que, portanto, questões linguísticas e direitos humanos são aspectos indissociáveis. Na concepção adotada por Beer (2016) é ressaltado que sem direitos linguísticos é impossível uma participação social igualitária. Dito de outro modo, não basta assegurar os direitos linguísticos somente em um determinado contexto social, na maioria das vezes - âmbito educacional. Os diferentes espaços sociais e acadêmicos devem ter, em sua base, a garantia e a efetividade desses direitos linguísticos. Tais direitos são materializados em políticas e práticas, que por sua vez, abrange a interlocução com outros campos como da educação, justiça e saúde, assim como articula-se como as políticas de tradução, que são inerentes às políticas linguísticas (SANTOS e FRANCISCO, 2018).

Karnopp (2010, p.174) afirma que diferentes "estratégias políticas, culturais e artísticas foram utilizadas pelo movimento surdo para denunciar a condição de pacientes da audiologia, deficientes auditivos ou sujeitos com 


\section{_tı.}

Injustiças sociais e direitos humanos nas literaturas surdas: olhares emergentes para saberes poéticos

Jonatas Rodrigues Medeiros • Silvana Aguiar dos Santos et al.

necessidades especiais". A autora utiliza a expressão "literatura surda" para conceitualizar "histórias que têm a língua de sinais, a identidade e a cultura surda presentes na narrativa" (KARNOPP, 2010, p. 161), ou, ainda, ratifica a autora que "a literatura surda está relacionada com a cultura surda" (KARNOPP, 2010, p. 171).

Mourão (2016, p. 228) também propõe que "a literatura surda tem o papel de fortalecer a comunidade surda, a língua de sinais e repassar para as gerações seguintes os valores de ser surdo". Como já abordamos, tomamos o conceito no plural, para demarcar produções poéticas que perpassam as questões da identidade e da cultura surda, e que também operam na relação com outras identidades e contextos múltiplos que atravessam diferentes poetas surdos. Fernandes e Medeiros (2020) apontaram que, nos últimos anos, floresceram múltiplas expressões de poesia sinalizada, cujo objetivo é a reivindicação do direito à informação. Os autores observam a relação dessas produções artísticas com enunciados verbovisuais, estética presente nas manifestações culturais surdas que alia, para além da textualidade em Libras, outros recursos semióticos, como imagens, ambiências, cenários, edição de vídeo, efeitos e legendas.

Weininger et al. (2014, p. 4) definem "[...] a poesia sinalizada como uma forma de arte linguística, mas também como um produto textual que incorpora elementos de outras linguagens como pintura, cinema, teatro, dança e arte performativa". Desse modo, transcrever esses discursos produzidos por poetas sinalizantes, que tenham como pauta os direitos humanos e as diferentes temáticas que tencionam esse campo, é de relevância, a fim de conhecer quais temáticas são enaltecidas por essas comunidades surdas. 


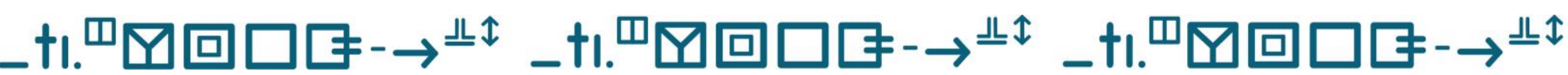

Injustiças sociais e direitos humanos nas literaturas surdas: olhares emergentes para saberes poéticos

Jonatas Rodrigues Medeiros • Silvana Aguiar dos Santos et al.

Tendo o ciberespaço como fonte de dados, é possível verificar vários grupos ciberculturais de surdos que trocam informações sobre os mais diversos assuntos em canais do Youtube, grupos abertos e fechados no Facebook e outras redes sociais. Tais grupos produzem uma quantidade incontável de vídeos em Libras com os mais diversos gêneros discursivos circulando através do suporte vídeo. Produções discursivas do cotidiano e da esfera literária e acadêmica são cada vez mais presentes e reivindicadas pelas comunidades surdas. Poetas surdas usam a internet e as redes sociais também como espaço de ciberativismo ${ }^{7}$, como ferramenta de visibilidade, para expandir as suas produções não só entre as comunidades surdas, mas para toda a sociedade.

\section{Poesia surda interseccional: minha luta é pela mulher, negra, surda, militante}

Diversos marcadores podem ser identificados nas poesias surdas, apresentando uma diversidade de categorias que são acionadas por poetas surdos, para além da própria cultura surda. Iniciamos com a poeta Gabriela Grigolom, conhecida como "Negabi", de Curitiba, Paraná. A poeta tem se destacado no uso da poesia como denúncia de injustiças sociais cometidas contra a mulher negra surda. Tendo seu primeiro destaque no Slam

\footnotetext{
${ }^{7}$ Alcântara (2015, p. 82) descreve sobre movimentos sociais e ciberativismo. A autora coloca que "[...] termos como ativismo midiático, midiativismo e mídia alternativa são utilizados, em muitos casos, enquanto sinônimos de ciberativismo. Ela ainda localiza que o movimento Zapatismo no México é considerado o marco inicial do ciberativismo.
} 


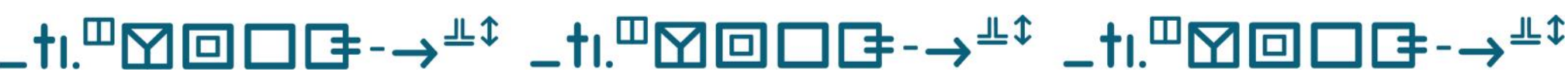

Injustiças sociais e direitos humanos nas literaturas surdas: olhares emergentes para saberes poéticos

Jonatas Rodrigues Medeiros • Silvana Aguiar dos Santos et al.

Contrataque $C W B^{8}$, seu poema ${ }^{9}$ ressoou como um manifesto interseccional da mulher negra surda que não encontra espaços nos movimentos sociais. Um dos motivos que explica esse manifesto origina-se na falta de direitos linguísticos, pela não comunicação em Libras e pela falta de acolhimento nos movimentos feminista e negro. Nesses espaços, a falta de acolhimento é um fato que merece ser considerado e discutido, assim como no movimento surdo. Embora neste último a língua de sinais seja uma constante, a poeta explica não sentir suas demandas como mulher negra nas pautas das comunidades surdas.

Suas poesias trazem, além da referência sobre a experiência de ser uma mulher negra surda, temáticas sobre a maternidade, desigualdade social, acessibilidade em espaços públicos e direitos linguísticos, e, ainda, evoca, em suas narrativas poéticas, referências como Marielle e Dandara. Sobre o conceito interseccionalidade dentro dos Estudos Surdos, Santos (2019, p. 25) registra que ele "assume grande relevância nos discursos de opressão e representações sociais da comunidade surda, possibilitando algumas reflexões quando cruzadas a outras categorias como gênero e classe social por exemplo".

Santos, Grigolom e Medeiros (2020) compreendem o papel de agência de Negabi, a partir da poesia subalterna de resistência, que se propõe localizada, textualizando seu território e sua vivência. Os autores utilizam o conceito de "poetas subalternos" inspirados no conceito de "investigadores subalternos", apresentado por Paddy Ladd (2013). Para Santos, Grigolom e

\footnotetext{
${ }^{8}$ Um relato sobre a experiência poética de Negabi é descrito no artigo Slam Resistência Surda (SANTOS; GRIGOLOM; MEDEIROS, 2020).

9 Disponível em: https://www.facebook.com/1917299225171306/videos/2133651183536108. Acesso em: 3 nov. 2020.
} 


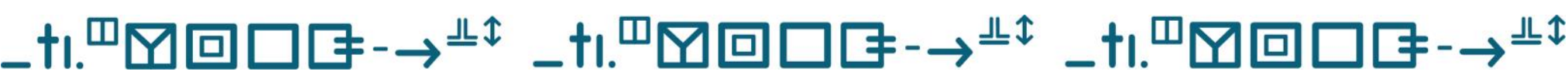

Injustiças sociais e direitos humanos nas literaturas surdas: olhares emergentes para saberes poéticos

Jonatas Rodrigues Medeiros • Silvana Aguiar dos Santos et al.

Medeiros (2020, p. 38), apesar dos poetas subalternos não se preocuparem com a ocupação de espaços acadêmicos, são sujeitos intelectuais que constroem "um conhecimento de resistência por meio de suas poesias".

Essa presença da literatura feminina como parte da literatura surda também foi observada por Sutton-Spence (2018). Segundo a autora, “[...] a literatura surda e a literatura feminina são bastante parecidas" (SUTTONSPENCE, 2018, p. 154), e as temáticas desenvolvidas pelas artistas surdas abordam "[...] conflito pessoal; um conflito familiar; ser mãe; vida romântica; problemas de amizade ou conflitos entre trabalho e vida pessoal". Possivelmente, o que difere a poesia de Negabi, da conceitualização apresentada por Sutton-Spence (2018) seja o caráter coletivo que sustenta a sua narrativa e o tom de denúncia, carregado no seu texto que também faz ressaltar o marcador racial.

Na poesia A minha luta é pela mulher negra surda (Figura 1), apresentada no programa Manos e Minas ${ }^{10}$, Negabi apresenta não uma pedra, mas uma árvore no meio do caminho. Ela sinaliza o contraste entre o sol lá fora e a angústia que a consome por dentro, as imposições do oralismo ${ }^{11}$ para que ela fale e a falta de acesso aos mais diversos espaços. Barreiras de comunicação estruturais e a bebida como fuga do terror abafado que a cerca.

\footnotetext{
10 Programa da televisão brasileira exibido na TV Cultura. Suas temáticas abordam a cultura urbana periférica, trazendo música, literatura e entrevista com representantes do hip-hop e outros gêneros ligados à cultura negra.

${ }^{11}$ Filosofia e método de ensino da fala para surdos aliado à medicalização da surdez. Ver Lane (1992), Skliar (1999), Fernandes (2011) e Rezende (2012).
} 


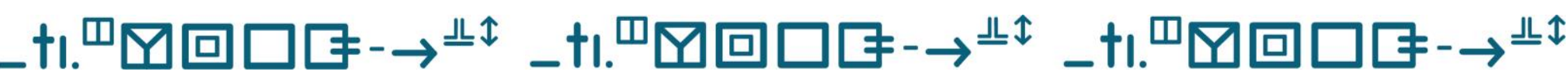

Injustiças sociais e direitos humanos nas literaturas surdas: olhares emergentes para saberes poéticos

Jonatas Rodrigues Medeiros • Silvana Aguiar dos Santos et al.

apontando à sua agência: "a minha luta é pela mulher, negra, surda, militante, somos a resistência".

Assim como Lélia Gonzalez, conforme Brito (2012, p. 103), tensiona a ideia de que "a discriminação [se apresenta] em dobro para com as mulheres não-brancas". Negabi atesta que sua experiência surda, interseccionada com os demais marcadores de raça, gênero e classe, constituem também uma bandeira política a ser levantada, convocando uma militância em prol de uma pauta que congregue identidades que sofrem opressões interseccionais, necessitando um combate há opressões interestruturais. ${ }^{12}$

Hooks (2019b, p.37) observa sobre a "postura de descolonização", que pode ser considerada como um processo político "[...] que vai além do ato de resistência à dominação [...]", é sempre um "[...] processo de recordar o passado, mesmo enquanto criamos novas formas de imaginar e construir o futuro".

Para um processo descolonizante, é necessário compreender que "colonialismo e racismo coincidem" (KILOMBA, 2019, p. 223). Assim, Negabi articula as identidades que a compõem como matéria da construção de uma pauta política pluralizada e localizada pelos marcadores de raça, gênero, classe e surdidade. Vale ainda mencionarmos que essas tensões são trazidas

\footnotetext{
12 Compreendemos que os modos estruturais de opressão se interrelacionam, tomando como base o Racismo Estrutural (ALMEIDA, 2020) e o Machismo Estrutural. Observamos que há engendrado, em nossa sociedade, também um Ouvintismo Estrutural. Ter isso em mente nos ajuda a refletir sobre as urgências de tirar debates de caixas fechadas e compreender as dinâmicas combinadas e inter-relacionadas de opressão, assim como aguerrir por políticas que agreguem sujeitos de direitos com identidades interseccionais. A pesquisa sobre o acesso de estudantes negros surdos no curso de Letras Libras, defendida por Santos (2019), aponta, por exemplo, a necessidade de políticas interseccionais, para que se garanta o efetivo acesso de estudantes negros surdos no Ensino Superior, já que os dispositivos legais não permitiram diretamente o aumento de matrícula de estudantes negros surdos nas universidades públicas, embora as políticas de acesso possibilitaram o crescimento de estudantes negros nesse nível de ensino e de surdos não negros.
} 


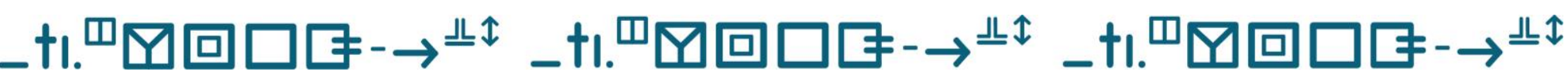

Injustiças sociais e direitos humanos nas literaturas surdas: olhares emergentes para saberes poéticos

Jonatas Rodrigues Medeiros • Silvana Aguiar dos Santos et al.

à tona por meio da língua de sinais, nesse caso a Libras. Desse modo, tensionar essas interseccionalidades à luz da efetivação dos direitos linguísticos nem sempre é pauta dos direitos humanos.

\section{Poesia surda, violência LGBTQI+ e violência estética}

A poeta surda Yanna Porcino, de Olinda, Pernambuco, tem uma rica produção que aborda, em Libras, temáticas como racismo, direito LGBTQI+, crítica aos padrões de beleza, direito do corpo da mulher ser livre e sobre sororidade (Figura 2). Suas poesias sinalizadas são registradas em vídeo e postadas em sua página do Instagram. No poema Amor é amor, a autora explicita a violência simbólica e física sofrida por gays, lésbicas e pessoas trans, denunciando o discurso religioso de pecado e culpabilização de sexualidades dissidentes da norma. O poema inicia-se com a felicidade e a dor de assumir-se em uma sociedade que lança olhares de julgamento baseados no ódio e finaliza com a afirmação de sua identidade e o direito de ser LGBTQI+.

Figura 2 - Poemas Amor é amor e Padrão beleza
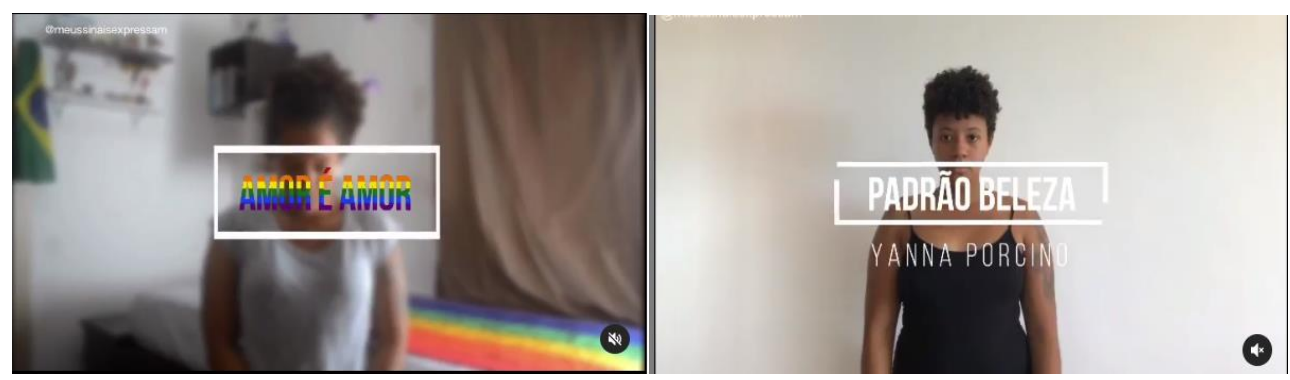

Fonte: Imagens extraídas da página do Instagram de Yanna Porcino, disponíveis em https://www.instagram.com/p/Byvz1F-FXVm/e https://www.instagram.com/p/B73rQiqJLrG/

Descrição da imagem: na primeira figura, aparece o título "Amor é Amor" em cores coloridas dentro de uma moldura. Ao fundo, Nayra, mulher negra, com blusa branca, cabeça baixa, aparece desfocada junto com o cenário de um quarto com a bandeira LGBTQIA+ estendida sobre a cama. Na parede, há uma cortina marrom, estantes de livros e objetos e uma pequena bandeira do Brasil. Na segunda 


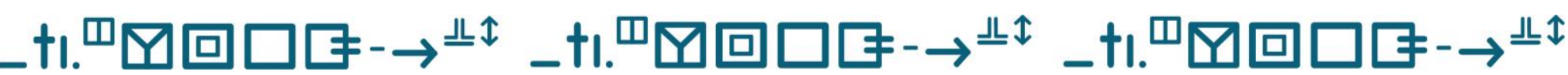

Injustiças sociais e direitos humanos nas literaturas surdas: olhares emergentes para saberes poéticos

Jonatas Rodrigues Medeiros • Silvana Aguiar dos Santos et al.

figura, aparece o título "Padrão Beleza" dentro de uma moldura com o nome Yanna Porcino abaixo. Ao fundo, em uma parede branca, aparece, olhando para frente, encarando a câmera, Yanna, mulher negra, cabelo Black curtos e camisa de alcinha na cor preta.

Dentro da literatura homoerótica e LGBTQI+ contemporânea, podemos observar diversas autorias que problematizam as questões de violência de gênero e sexualidade correlacionando o debate com os direitos humanos, tomando a literatura como “instrumento possível de resistência e problematização de contextos sociais e políticos" (CARVALHO, 2019, p. 113). Souza (2016) retrata como o desejo e a violência estão presentes na literatura homoerótica, assim como Camargo (2010), que ao trabalhar com os textos de Caio Fernando de Abreu, descreve os atos de violência física e verbal por meio de personagens gays, que representam uma ficção da observação do real.

Em Padrão Beleza (postado em 26 de janeiro de 2020), a poeta faz crítica aos procedimentos estéticos, tais como: afinação do nariz, diminuição de cintura, corpo magro, silicones nos seios e glúteos, cabelos lisos e cílios alongados, aos quais as mulheres se submetem em nome de um modelo estético pautado na sociedade. O poema inicia-se com a sinalização de uma fábrica de bonecas, fazendo alusão à uma produção em massa de um biotipo de corpo e estética a ser apreciado e desejado pelas mulheres. Sem nomear, a narrativa induz à imagem da mulher loira, magra, com seios e glúteos duros e fartos.

A crítica de Yanna Porcino dialoga com Hooks (2019b) ao permitir as perguntas sobre quais políticas de representação nós sonhamos, olhamos, criamos e agimos. Hooks (2019b, p. 36) percebe que o campo de representação permanece como um campo de luta a ser examinado criticamente, compreendendo que "as imagens têm uma intenção 


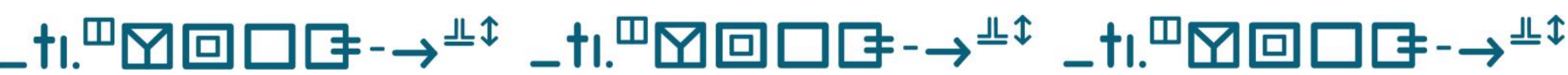

Injustiças sociais e direitos humanos nas literaturas surdas: olhares emergentes para saberes poéticos

Jonatas Rodrigues Medeiros • Silvana Aguiar dos Santos et al.

ideológica", salientando o lugar de agência do olhar crítico das pessoas negras e o olhar sobre o Outro e as representações como um lugar de resistência (HOOKS, 2019b, p. 217). Podemos observar que, no poema de Porcino, há uma constatação das políticas de representação da branquitude e o que Hooks (2019b, p. 283) denominaria de "ambição loira"13.

Cechin e Silva (2012a, 2012b) comentam sobre o uso de bonecas como parte de uma pedagogia cultural que objetiva contribuir com a supremacia de um tipo de corpo, raça e comportamento, que introjeta na criança um sentimento do belo padrão. Esse exemplo dos conceitos do que é belo e do que é ser padrão poderiam ser observados em bonecas Barbie que, conforme as autoras, "[...] mais de 50 anos da sua criação, Barbie continua preponderantemente magra, branca, com cabelos loiros, compridos e lisos" (CECHIN; SILVA, 2012a, p. 13). E mesmo com um marketing multicultural pós anos 1990, explorando uma diversidade étnica, reforçamse estereótipos e perpetuam-se o físico da magreza e seios grandes. Para Oliveira (2016, p. 4), mesmo retratando as diferenças, a boneca Barbie permanece em sua "supremacia branca". Na sequência de sua narrativa, a poeta Yanna Porcino direciona o olhar crítico da sociedade para mulheres fora do padrão ditado e o quanto há um processo clínico estético voraz ao criar-se o fascínio cultural da beleza loira, que só pode ser alcançado "por meio da imitação e do artifício" (HOOKS, 2019b, p. 284).

O mesmo poema foi repostado pela poeta em versão Stop motion (Figura 3) - postado em 1 de agosto de 2020 -, porém a poeta se utiliza da

\footnotetext{
13 Hooks (2019b) faz menção à turnê Madonna de 1990, que carregava o título Blonde ambition. A autora problematiza a supremacia branca como realidade política em que a branquitude permite que pessoas loiras tenham mais possibilidades de serem bemsucedidas, assim como suas aparências são mais bem quistas e requisitadas.
} 


\section{_tı.}

Injustiças sociais e direitos humanos nas literaturas surdas: olhares emergentes para saberes poéticos

Jonatas Rodrigues Medeiros • Silvana Aguiar dos Santos et al.

O desejo de ser compreendida e da tradução de sua mensagem demonstra a agência não apenas poética, mas também pedagógica ao tornar sua poesia visual e compreensível para além de uma linguagem verbal. Essa estratégia da poeta coloca em debate a seguinte linha de raciocínio: mesmo que os direitos linguísticos permitam à poeta a expressão de sua poesia, ela precisa acionar a tradução como uma forma pedagógica de se fazer entendida por aqueles que não compartilham de sua língua. Desse modo, a provocação de que o direito à tradução e o direito linguístico sejam problematizados como garantia dos direitos humanos é condição fundamental para o exercício ético e de dignidade humana diante das populações que não compartilham da língua oficial de um país.

\section{Poesia surda da quebrada: "Quer conhecer a poesia da quebrada?"}

Finalizamos com a produção poética de Edvaldo Santos, de São Paulo capital, amplamente conhecido como Edinho Poeta. O poeta e arte-educador tem um repertório de poesias de difícil contabilidade, com uma inserção forte na poesia de rua. Foi finalista de várias competições, tendo o poema "Mudinho" como um dos mais aclamados e conhecidos da sua trajetória. Sua versatilidade poética permite atuações não apenas em eventos de Slams, mas também em produções de poesias audiovisuais editadas pelo próprio poeta. Suas temáticas estão sempre relacionadas à sua vivência e experiência como homem, negro, surdo e seu orgulho de $\operatorname{ser}^{15}$. Edinho reclama os estereótipos recebidos pela sociedade ouvintista; condena o

\footnotetext{
${ }^{15}$ Disponível em: https://www.instagram.com/p/CE_zxnLjmjC/. Acesso em: 5 nov. 2020.
} 


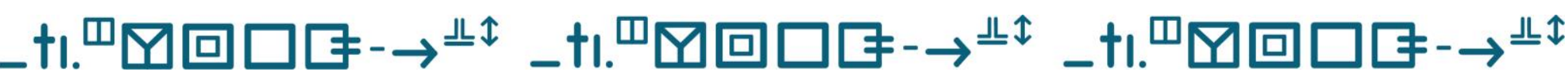

Injustiças sociais e direitos humanos nas literaturas surdas: olhares emergentes para saberes poéticos

Jonatas Rodrigues Medeiros • Silvana Aguiar dos Santos et al.

sistema ouvintista que o obriga aprender a língua portuguesa ${ }^{16}$; subverte o opressor, denominado como "ouvintinho" em detrimento do estereótipo de "mudinho"17 para quem não sabe Libras; proclama a Libras como sua voz e sua liberdade ${ }^{18}$; denuncia o privilégio ouvinte de uma sociedade estruturalmente ouvintista ${ }^{19}$.

Escolhemos, para exemplificar a produção de Edinho, uma poesia intitulada Poesia da Quebrada ${ }^{20}$ (Figura 4), devido às referências evocadas e à mensagem performatizada em uma poesia audiovisual. Esse poema utiliza cenários da sua paisagem cotidiana, retratando, a partir de sua inventividade intelectual, as injustiças acometidas em seu território e a denúncia do epistemicídio com o não reconhecimento de intelectuais negros surdos. Assim, Edinho também se localiza a partir da literatura negra ou, como explica Brito (2020), da literatura negra surda, compreendida "como lugar de representação, marcada pela produção poética formulada, sentida e transmitida em libras, pensada a partir da visualidade, das subjetividades, de reconhecer-se e ser reconhecido, de sentir-se e de ser indissociavelmente percebido como negro surdo"21.

16 Disponível em: https://www.instagram.com/p/CE-MxHcpnaG/ e outra versão em https://www.instagram.com/p/CFKsyrd]8Wa/. Acesso em: 5 nov. 2020.

17 Disponível em: https://www.instagram.com/p/CFLgEjOpTn_. Acesso em: 5 nov. 2020.

${ }_{18}$ Disponível em: https://www.instagram.com/p/CFC1/tbp9N-l. Acesso em: 5 nov. 2020.

19 Disponível em: https://www.instagram.com/p/CDFvWQUpoG2/. Acesso em: 5 nov. 2020.

20 Disponível em: https://www.instagram.com/p/CC4OV88pkOG/. Acesso em: 5 nov. 2020.

${ }^{21}$ Fala da autora proferida na Live Literatura Negra Surda - Axé Libras, ocorrida em 27 de julho de 2020. A pesquisadora vem trabalhando com a temática em sua tese de doutoramento, embora não tenha publicado textos acadêmicos ainda sobre a temática. Reconhecendo a urgência da discussão, Ires Brito tem participado de várias lives a fim de disseminar a literatura negra surda. 


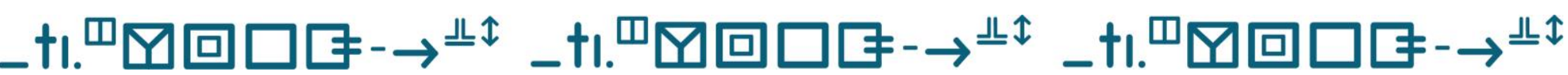

Injustiças sociais e direitos humanos nas literaturas surdas: olhares emergentes para saberes poéticos

Jonatas Rodrigues Medeiros • Silvana Aguiar dos Santos et al.

negro e surdo". Carneiro (2005) afirma que o tema do epistemícidio passa pelo não reconhecimento de intelectuais negros e militantes negros como fonte primária de pesquisa. Segundo a autora, “o epistemicídio é, para além da anulação e desqualificação do conhecimento dos povos subjugados, um processo persistente de produção da indigência cultural" (CARNEIRO, 2005, p. 97).

Edinho avança no texto fazendo uma crítica à história da língua de sinais, baseada tão somente em evidências históricas da Europa e da América do Norte: "acha que a língua de sinais existe somente na Europa? Existe também a língua de sinais diaspórica". A contestação desse lugar eurocêntrico dos discursos sobre as línguas de sinais evidencia-se nas pesquisas acadêmicas sobre a Libras e as Literaturas Surdas, que têm seus olhos voltados aos países do Norte, assim como seus arcabouços teóricos geopoliticamente filiados aos pensamentos teóricos produzidos ao Norte ${ }^{23}$. Edinho salienta que: "não há registros em livros, mas há marcas em seres humanos".

Santos e Mota (2020, p. 87), ao comentarem sobre a poesia marginal, colocam que "as emergências da quebrada são expressas por meio de nossas músicas, danças, crenças, roupas, estilos e da rua, com sua maneira peculiar de existência periférica".

O poeta continua trazendo referências do seu espaço de resistência: "Conceição Evaristo, Maria Carolina de Jesus e poetas negros, me ensinam muito".

\footnotetext{
${ }^{23}$ As línguas de sinais modernas no continente africano podem ser observadas a partir das produções acadêmicas dos seus respectivos países. Godoy (2020), ao pesquisar sobre a língua de sinais indígena Ka'apor, traz dados sobre a cultura gestual histórica reconhecida em Povos da África Ocidental. Segundo o autor, "[...] o povo dogon de Mali, onde há sinais caseiros, e o povo yorubá de Akure (Nigéria), onde há diferentes estados de línguas de sinais" (GODOY, 2020, p. 188).
} 


\section{_t..}

Injustiças sociais e direitos humanos nas literaturas surdas: olhares emergentes para saberes poéticos

Jonatas Rodrigues Medeiros • Silvana Aguiar dos Santos et al.

Ele recupera a multiplicidade de vozes, temática comentada por Hooks (2019a) e Brito (2012, p. 125), a qual ratifica o "espectro de uma intelectualidade negra interventora", que desconstrói a imagem canônica do intelectual academicista que lembra a persona aristocrática.

Ao denunciar o extermínio da população negra no Brasil, Edinho traz a presença em versos: "O sistema tenta nos calar Mariele Presente, o sistema tenta nos chocar Ágatha presente! O sistema tenta nos exterminar $12345 \ldots 80$ tiros". Sem "meios sinais", sua narrativa é contundente em dizer que "nós estamos na mira" e, por isso, convoca quem o assiste para lutar: "vamos lutar ou morrer". A demarcação de território como constituinte do seu lugar de fala sobre a quebrada é lembrada no poema, reafirmando que "não vou ficar quieto, nem fodendo, eu vou incomodar esse mundo!". Santos e Mota (2020, p. 99) também se posicionam do seguinte modo sobre a poesia periférica surda: “Nossos versos têm histórias, denúncias de desigualdades e diversas camadas de exclusão [...]. Poetizamos dores, batalhas e nossa luta secular pelo direito à nossa existência".

Aspectos do ponto de vista da produção estética e narrativa do poema também podem ser observados na Poesia da quebrada, pois Edinho faz uso de recursos cinematográficos, com diferentes enquadramentos e diferentes ângulos (Figura 5), sabendo dos efeitos que o uso de tal linguagem na montagem pode causar em quem a assiste. Diferentes paisagens são escolhidas compondo a semiótica daquilo que o seu texto diz. Podemos considerar tal narrativa como videopoesia, uma vez que "o videopoema pode ser considerado resultado de processos de semiose e intersemiose entre regimes semióticos diferentes que se encontram num espaço intersticial" (FERREIRA, 2004, p. 38). 


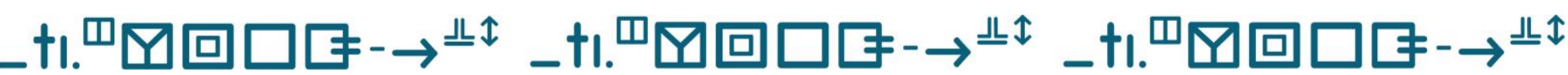

Injustiças sociais e direitos humanos nas literaturas surdas: olhares emergentes para saberes poéticos

Jonatas Rodrigues Medeiros • Silvana Aguiar dos Santos et al.

Figura 5 - Poesia da quebrada ${ }^{24}$ : enquadramentos, planos cinematográficos e cenários

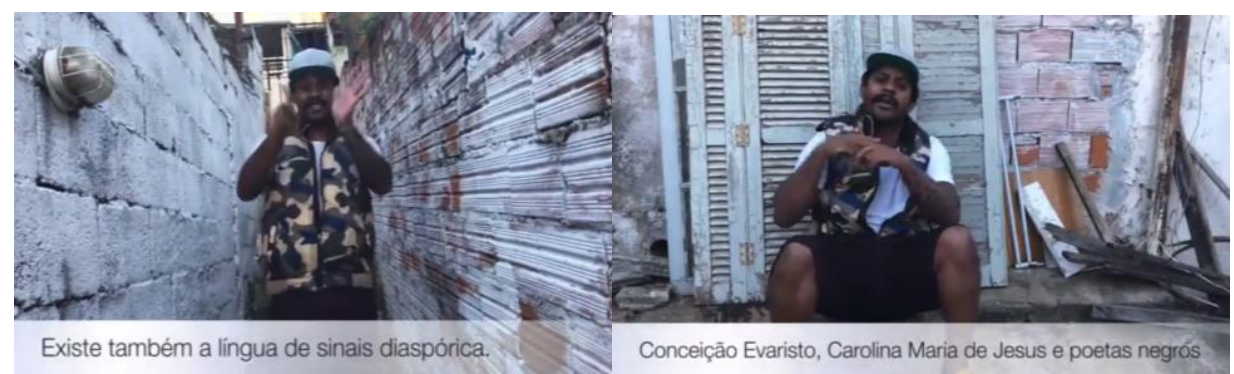

Fonte: Imagens extraídas de https://www.instagram.com/p/CC4OV88pkOG/

Descrição da imagem: Na primeira imagem, aparece Edinho, homem negro de bigode, com boné cinza, camisa branca e colete estampa militar. Sinaliza em um beco de paredes batida. Na parte inferior da imagem, há a legenda "Existe também a língua de sinais diaspórica". Na figura seguinte, Edinho, com o mesmo traje, está sentado na calçada. Atrás há uma porta velha e madeiras aleatórias atiradas ao chão e encostadas na parede. Na legenda, na parte inferior da imagem, se lê "Conceição Evaristo, Carolina Maria de Jesus e poetas negros".

A tradução intersemiótica também se faz visível, quando observamos a legenda sendo utilizada em alguns momentos como parte estética do seu poema, o que Fernandes e Medeiros (2020) conceitualizam como verbovisualidade nos artefatos culturais das comunidades surdas. Trazendo ainda para o contexto das injustiças sociais, podemos refletir, conforme Kilomba (2019, p. 162) coloca, que "a linguagem do trauma é, nesse sentido, física, gráfica e visual, articulando o efeito incompreensível da dor".

Pensar nas injustiças sociais e nos direitos humanos nas Literaturas Surdas é pensar em uma ética interseccional que se comprometa com os direitos linguísticos basilares dos direitos ditos humanos. A repressão linguística já foi alvo de muitos estudos, conforme demonstramos no texto, porém é preciso visualizar não somente os efeitos da opressão, mas garantir

\footnotetext{
24 Tradução @motaagain e @en.cantaviic. Voz: @igorkierke. Filmagem: @nayudapoesia. Edição de vídeo: Edinhopoesia. Edição de som e batida: @jonatasmedeiros. Música: [FREE] instrumental Uso Libre beat Rap Prod. Beato Cvrry (Informação contida na descrição do poema postado no Instagram).
} 


\section{_t..}

Injustiças sociais e direitos humanos nas literaturas surdas: olhares emergentes para saberes poéticos

Jonatas Rodrigues Medeiros • Silvana Aguiar dos Santos et al.

humanos. A potencialidade do uso do vídeo e os programas de edição ampliam a expressividade linguística e discursiva das comunidades surdas, bem como suas literaturas, sendo uma característica de importante descrição para compreender o gênero textual poesia em Libras.

Este texto permitiu-nos registrar determinados discursos de denúncia das mazelas sociais para com as comunidades surdas sinalizantes. Identificamos as diversas temáticas que esses poetas circulam dentro dos direitos humanos, operando em debates interseccionais de raça, gênero e classe, além da violência LGBTQI+ e a violência estética. Acreditamos que outras pesquisas possam trabalhar com essas temáticas de forma a analisar as diversas literaturas surdas que tratam sobre direitos humanos de forma a aprofundar os marcadores aqui levantados. Pesquisas que se interessem pela trajetória desses poetas, assim como seus meios de produção, podem auxiliar na circulação do pensamento surdo intelectual produzido por meio da literatura.

O olhar sobre a estética dessas performances literárias pode, portanto, ampliar o campo literário brasileiro, que ainda tem seu cânone pautado na literatura ouvinte de modalidade escrita. Ressaltamos também a importante interlocução entre a literatura surda, direitos linguísticos e as políticas linguísticas e de tradução. Mas, enfatizamos que o debate literário perpassa o campo da língua e envolve também discussões voltadas à raça, gênero, classe e sexualidade.

Por fim, acreditamos serem importantes, pesquisas que recortem a presença dos intérpretes de Libras-Português nessas temáticas de denúncia. É fundamental observar as práticas desses sujeitos, assim como os territórios ideológicos permeados por quem se habilita a transladar os textos poéticos, os quais carregam narrativas de dores, de injustiças, de 


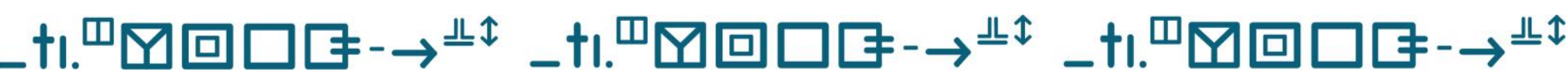

Injustiças sociais e direitos humanos nas literaturas surdas: olhares emergentes para saberes poéticos

Jonatas Rodrigues Medeiros • Silvana Aguiar dos Santos et al.

representatividade e de lugares de fala. Quem traduz Literaturas Surdas de (in)justiça social e traumas? Cabe tal tradução a qualquer intérprete?

\section{Referências}

ALCÂNTARA, Lívia Moreira de. Ciberativismo e movimentos sociais: mapeando discussões. Aurora: revista de arte, mídia e política, São Paulo, v. 8, n. 23, p. 73-97, jun./set. 2015.

ALMEIDA, Silvio Luiz de. Racismo Estrutural. São Paulo: Sueli Carneiro; Editora Jandaíra, 2020.

BALDI, César Augusto. Para uma sociologia das ausências da descolonização dos direitos humanos: notas iniciais sobre os aportes afros. Hendu - Revista Latino-Americana de Direitos Humanos, Belém, v. 6, n. 1, p. 47-68, nov. 2015. DOI: http://dx.doi.org/10.18542/hendu.v6i1.2461

BEER, Hanna. Direitos Linguísticos como direitos fundamentais: as políticas linguísticas para as comunidades surdas no ordenamento jurídico brasileiro. 2016. Trabalho de Conclusão de Curso (Bacharelado em Direito) Universidade Federal de Juiz de Fora, Juiz de Fora, 2016.

BERNARDINO-COSTA, Joaze. A prece de Frantz Fanon: Oh, meu corpo, faça sempre de mim um homem que questiona!. Civitas, Revista de Ciências Sociais, Porto Alegre, v. 16, n. 3, p. 504-521, 2016. DOI: https://doi.org/10.15448/1984-7289.2016.3.22915

BRASIL. Decreto $N^{\circ}$ 5.626, de 22 de dezembro de 2005. Regulamenta a Lei $n^{\circ} 10.436$, de 24 de abril de 2002, que dispõe sobre a Língua Brasileira de Sinais - Libras, e o art. 18 da Lei n ${ }^{\circ}$ 10.098, de 19 de dezembro de 2000. Diário Oficial da União: seção 1, Brasília, DF, n. 246, p. 28-30, 23 dez. 2005.

BRITO, Ires dos Anjos. Lélia Gonzales: A Nêga ativa! In: Santiago, Ana Rita et al. (org.). Entre o pensamento de Lélia Gonzales e a palavra poética. Cruz das Almas. Bahia: UFRB, 2014. p. 18-36.

BRITO, Ires dos Anjos. Revisitando os percursos intelectuais e políticos de Beatriz do Nascimento e Lélia Gonzalez. 2012. Dissertação (Mestrado em Estudos Étnicos e Africanos) - Faculdade de Filosofia e Ciências Humanas da Universidade Federal da Bahia, Salvador, 2012.

BRITO, Ires dos Anjos. In: MEIRA, Wermerson. Terminologias negroafricanas e a literatura negra surda. Plataforma Youtube. 27 de julho de $2020 . \quad$ Disponível em < https://www.youtube.com/watch?v=Qr0oT5yBNv0\&t=4008s >

CAMARGO, Flávio Pereira. Homoerotismo e violência em "Terça-feira gorda", conto de Caio Fernando Abreu. Fazendo Gênero: diásporas, diversidades, 


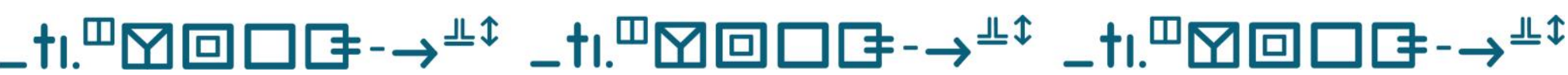

Injustiças sociais e direitos humanos nas literaturas surdas: olhares emergentes para saberes poéticos

Jonatas Rodrigues Medeiros • Silvana Aguiar dos Santos et al.

deslocamentos, n. 9, ago. 2010. Disponível em: http://www.fg2010.wwc2017.eventos.dype.com.br/resources/anais/127784 3817_ARQUIVO_HOMOEROTISMOEVIOLENCIAEMTERCAFEIRAGORDA.pdf. Acesso em: 22 nov. 2020.

CARDOSO, Sebastião Marques; SILVA, Helen Carlo Souza da. Representações da violência no conto "Ana Davenga", de Conceição Evaristo. Revista da Anpoll, Florianópolis, n. 43, p. 59-74, jul./dez. 2017. DOI: http://dx.doi.org/10.18309/anp.v1i43.1038

CARNEIRO, Vinícius Gonçalves. Reflexões quanto à literatura marginal brasileira: comparando Ferréz a sua tradição literária. Estudos de Literatura Brasileira Contemporânea, n. 50, p. 254-276, 2017. DOI: https://doi.org/10.1590/2316-40185017

CARNEIRO, Aparecida Sueli. A construção do outro como não-ser como fundamento do ser. 2005. Tese (Doutorado em Educação) - Universidade de São Paulo, São Paulo, 2005.

CARVALHO, Elis Silva de. O extermínio das pessoas trans: a violência de gênero como enredo na literatura e na realidade. In: SMITH, Andreza do Socorro Pantoja de Oliveira. (coord.). Direitos humanos de grupos diferenciados: mulheres, transmulheres e travestis em foco. Porto Alegre: Editora Fi, 2019. p. 114-142.

CECHIN, Michelle Brugnera Cruz; SILVA, Thaise da. A boneca Barbie na cultura lúdica: brinquedo, infância e subjetivação. Zero-a-Seis, Florianópolis, v. 14, n. 26, p. 1-22, jul./dez. 2012a. DOI: https://doi.org/10.5007/19804512.2012n26p20

CECHIN, Michelle Brugnera Cruz; SILVA, Thaise da. Assim falava Barbie: uma boneca para todos e para ninguém. Fractal: Revista de Psicologia, Niterói, v. 24, n. 3, p. 623-638, 2012b. DOI: https://doi.org/10.1590/S198402922012000300012

CEl, Vitor. O teor testemunhal da poesia marginal: política, filosofia, desbunde. Curitiba: UFPR, 2011.

CÉSAIRE, Aimé. Discursos sobre o colonialismo. Tradução Claudio Willer. São Paulo: Veneta, 2020.

DAMASCENA. Alexandre Silva. A literatura a partir do território: a relação entre forma e conteúdo em Ferréz. 2015. Dissertação (Mestrado em Letras Vernáculas) - Universidade Federal do Rio de Janeiro, Rio de Janeiro, 2015.

DALCASTAGNÈ, Regina. Sobre guerras, ruídos e esquecimentos. In: DALCASTAGNÈ, Regina et al. (org.). Literatura e Direitos Humanos. Porto Alegre: Zouk, 2018. p. 31-46.

DALCASTAGNÈ, Regina; DUTRA, Paula Q.; FREDERICO, Graziele. Literatura e Direitos Humanos. Porto Alegre: Zouk, 2018. 


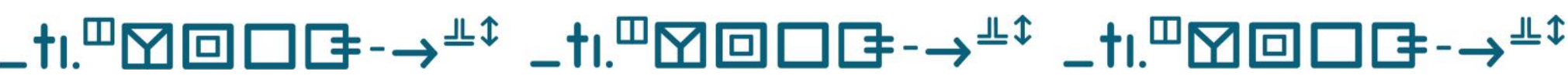

Injustiças sociais e direitos humanos nas literaturas surdas: olhares emergentes para saberes poéticos

Jonatas Rodrigues Medeiros • Silvana Aguiar dos Santos et al.

DELGADO, Gabriel Estides. Potencialidades e limites da literatura. In: DALCASTAGNÈ, Regina et al. (org.). Literatura e Direitos Humanos. Porto Alegre: Zouk, 2018. p. 181-188.

EAGLETON, Terry. O que é literatura? In: EAGLETON, Terry. Teoria da literatura: uma introdução. Tradução de Waltensir Dutra. São Paulo: Martins Fontes, 2006. p. 1-24.

FANON, Frantz. Pele negra, máscaras brancas. Tradução Renato da Silveira. Salvador: EDUFBA, 2008.

FERNANDES, Sueli. Educação de Surdos. 2. ed. Curtitiba: Ibepex, 2011.

FERNANDES, Sueli; MOREIRA, Laura Ceretta. Políticas de educação bilíngue para os estudantes surdos. Educar em Revista, Curitiba, v. 33, n. 3, p. 127150, dez. 2017. DOI: https://doi.org/10.1590/0104-4060.51048

FERNANDES, Sueli; MEDEIROS, Jonatas. Libras e arte: manifestações verbovisuais de artefatos culturais da comunidade surda. In: FERNANDES, Sueli; MEDEIROS, Jonatas Rodrigues. Libras e arte: manifestações verbovisuais de artefatos culturais da comunidade surda. Revista Espaço, $\mathrm{n}$. 54, p. 15-29, 2020.DOI: http://dx.doi.org/10.20395/re.v0i54 Disponível em: $<$ https://www.ines.gov.br/seer/index.php/revista-

espaco/article/view/677/744> Acesso: 20 dez. 2020.

FERREIRA, Ana Paula. Videopoesia: uma poética da intersemiose. Em Tese, Belo Horizonte, n. 8, p. 37-45, 2004. DOI: http://dx.doi.org/10.17851/19820739.8.0.37-45

GINZBURG, Jaime. Literatura e direitos humanos: notas sobre um campo de debates. Memórias da repressão. Santa Maria: UFSM/PPGL, 2008.

GODOY, Gustavo. Os Ka'apor, os gestos e os sinais. 2020. Tese (Doutorado em Antropologia Social) - Universidade Federal do Rio de Janeiro, Rio de Janeiro, 2020.

GONÇALVES, Ricardo Juozepavicius. A superioridade racial em Immanuel Kant: as justificações da dominação europeia e as suas implicações na América Latina. Kínesis, Marília, v. VII, n. 13, p. 179-195, jul. 2015. DOI: https://doi.org/10.36311/1984-8900.2015.v7n13.5452

HALL, Stuart. A identidade cultural na pós-modernidade. 11. ed. Rio de Janeiro: DP\&A, 2006.

HALL, Stuart. Da Diáspora: Identidades e mediações culturais. Tradução Adelaine La Guardia Resende et al. 2. ed. Belo Horizonte: Editora UFMG, 2018. HOOKS, Bell. Erguer a voz: pensar como feministas, pensar como negra. Tradução Cátia Bocaiuva Maringolo. São Paulo: Elefante, 2019a.

HOOKS, Bell. Olhares negros: raça e representação. Tradução Stephanie Borges. São Paulo: Elefante, 2019b. 


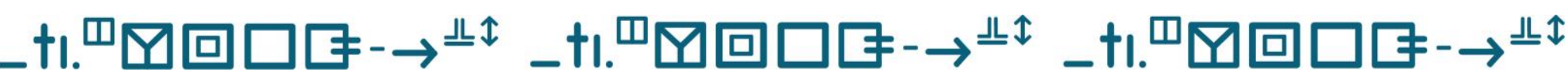

Injustiças sociais e direitos humanos nas literaturas surdas: olhares emergentes para saberes poéticos

Jonatas Rodrigues Medeiros • Silvana Aguiar dos Santos et al.

JESUS, Amanda Julieta; SOUZA, Florentina da Silva. Nossa arma-palavra: o ativismo intelectual das mulheres negras no poetry slam. REVELL - Revista de Estudos Literários da UEMS, [s. I.], v. 1, n. 24, p. 332-350, 2020. KARNOPP, Lodenir Becker. Literatura Surda. EDT - Educação Temática Digital, v. 7, p. 2, 2006.

KARNOPP, Lodenir Becker. Produções culturais de surdos: análise da literatura surda. Cadernos de Educação, Pelotas, n. 36, p. 155-174, maio/ago. 2010.

KILOMBA, Grada. Memórias da plantação: Episódios de racismo cotidiano. Tradução Jess Oliveira. Rio de Janeiro: Cobogó, 2019.

LADD, Paddy. Em busca da Surdidade 1: colonização dos surdos. Tradução Mariani Martini. Lisboa: Surd'Universo, 2013.

LANE, Harlan. A máscara da benevolência: a comunidade surda amordaçada. Tradução Cristina Reis. Lisboa: Instituto Piaget, 1992. (Coleção Horizontes Pedagógicos).

LEHNEN, Leila. O direito à poesia. In: DALCASTAGNÈ, Regina et al. (org.). Literatura e Direitos Humanos. Porto Alegre: Zouk, 2018. p. 13-29.

MBEMBE, Achille. Crítica da razão negra. Tradução Sebastião Nascimento. 3. ed. São Paulo: $\mathrm{n}-1$ ediç̧̃es, 2019.

MOURÃO, Cláudio Henrique Nunes. Literatura Surda: produções culturais de surdos em língua de sinais. 2011. Dissertação (Mestrado em Educação) Universidade Federal do Rio Grande do Sul, Porto Alegre, 2011.

MOURÃO, Cláudio Henrique. Literatura Surda: experiência das mãos literárias. Tese (Doutorado em Educação) - Universidade Federal do Rio Grande do Sul, Porto Alegre, 2016.

MUNANGA. Kabengele. Rediscutindo a mestiçagem no brasil. Identidade nacional versus identidade negra. 5 ed. rev. amp. - Belo Horizonte :Autêntica Editora, 2019.

NAKAGAWA, Hugo Eiji Ibanhes. Culturas Surdas: o que se vê, o que ouve. 2012. Dissertação (Mestrado em Cultura e Comunicação) - Universidade de Lisboa, Lisboa, 2012.

OLIVEIRA, Luiz Henrique Silva de. "Escrevivência" em Becos da memória, de Conceição Evaristo. Revista Estudos Feministas, Florianópolis, v. 17, n. 2, p. 621-623, 2009. DOl: http://dx.doi.org/10.1590/S0104-026X2009000200019 OLIVEIRA, Gabriela Miranda. Da menina à mulher: O empoderamento feminino como estratégia de publicidade na propaganda da boneca Barbie em detrimento da vaidade e submissão do primeiro comercial (1961-2015). In: ENCONTRO REGIONAL DE HISTÓRIA, 20., 2016, Uberaba. Anais eletrônicos [...]. Uberaba: ANPUH, 2016. Disponível em: 


\section{_t..}

Injustiças sociais e direitos humanos nas literaturas surdas: olhares emergentes para saberes poéticos

Jonatas Rodrigues Medeiros • Silvana Aguiar dos Santos et al.

http://encontro2016.mg.anpuh.org/resources/anais/44/1469208654_ARQUI VO_TextocompletoAnpuhDameninaamulher.pdf. Acesso em: 20 nov. 2020. ОтО, Alejandro de. Notas metodológicas en contextos poscoloniales de investigación. In: OTO, Alejandro de et al. (org.). Metodologías en contexto: intervenciones en perspectiva feminista, poscolonial, latinoamericana. Ciudad Autónoma de Buenos Aires: CLACSO, 2017. p. 13-31. Disponível em: http://biblioteca.clacso.edu.ar/clacso/se/20180209122042/Metodologias_en _contexto.pdf. Acesso em: 25 nov. 2020.

THOMA. A.S. O cinema e a flutuação das representações surdas - "Que drama se desenrola neste filme? Depende da perspectiva..." Tese do Programa de Pós Graduação em Educação. UFRGS, Rio Grande do Sul. 2002. Disponível em: <https://www.lume.ufrgs.br/handle/10183/37838> Aceesado em 20. dez. 2020.

PALMEIRA, Francineide Santos; SOUZA, Florentina da Silva. Representações de gênero e afrodescendência na obra de Conceição Evaristo. In: ENECULTENCONTRO DE ESTUDOS MULTIDISCIPLINARES EM CULTURA, 4., 2008, Salvador. Anais eletrônicos [...]. Salvador: ENECULT, 2008. Disponível em: http://www.cult.ufba.br/enecult2008/14440.pdf. Acesso em: 25 nov. 2020. PEREIRA, Rodrigo da Rosa. A periferia em Conceição Evaristo e Esmeralda Ribeiro: questões de gênero, raça e classe. Estudos de Literatura Brasileira Contemporânea, Rio de Janeiro, n. 49, p. 33-50, 2016. DOI: https://doi.org/10.1590/2316-4018493

PIZA, Suze. Nota sobre o legado improvável de Kant: a crítica como método para produção de filosofias. Kant e-Prints, Campinas, v. 14, n. 3, p. 175-192, 2019.

QUADROS, Ronice.; SUTTON-SPENCE, Rachel. Poesia em Língua de Sinais: traços da identidade surda. In: QUADROS, Ronice Muller de. (ed.). Estudos Surdos 1. Petrópolis: Editora Azul, 2006. p. 110-165.

QUEIROZ, Jefferson Justino de. Literatura eletrônica: videopoema e videonarrativa, novas resistências à máquina capitalista. 2018. Dissertação (Mestrado em Literatura e Interculturalidade) - Universidade Estadual da Paraíba, Campina Grande, 2018.

REZENDE, Patrícia. L. F. Implante coclear e resistência surda. Curitiba: CRV, 2012.

RODRIGUES, Carlos Henrique; BEER, Hanna. Direitos, políticas e línguas: divergências e convergências na/da/para educação de surdos. Educação \& Realidade, Porto Alegre, v. 41, n. 3, p. 661-680, 2016. DOI: http://dx.doi.org/10.1590/2175-623661114 


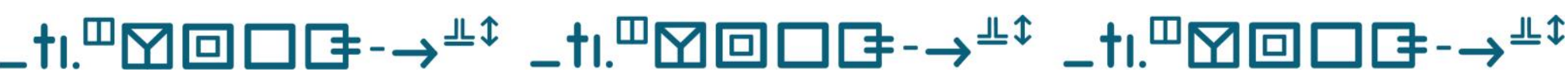

Injustiças sociais e direitos humanos nas literaturas surdas: olhares emergentes para saberes poéticos

Jonatas Rodrigues Medeiros • Silvana Aguiar dos Santos et al.

SANTANA, Marluce Freitas de. Desconstrução do patriarcado em Ponciá Vicêncio: à guisa de um sumário. Seminário Interlinhas, Alagoinhas, v. 2, n. 2, p. 153-163, 2014.

SANTOS, Silvana Aguiar dos; FRANCISCO, Camila. Políticas de tradução: um tema de políticas linguísticas? Fórum Linguístico, v. 15, n. 1, 2018, p. 29392949.

SANTOS, Rhaul Lemos de. Negros/as surdos/as no Ensino Superior: mapeando cursos de graduação de Letras Libras. 2019. Dissertação (Mestrado em Educação) - Universidade federal do Paraná, Curitiba, 2019.

SANTOS, Rhaul Lemos de; GRIGOLOM, Gabriela; MEDEIROS, Jonatas Rodrigues. Slam resistência surda: Curitiba: movimento e poesia. In: FERNANDES, Sueli; MEDEIROS, Jonatas Rodrigues. Libras e arte: manifestações verbovisuais de artefatos culturais da comunidade surda. Revista Espaço, n. 54, p. 31-53, nov. 2020. Disponível em: $<$ https://www.ines.gov.br/seer/index.php/revistaespaco/article/view/678/745> Acesso em: 20. dez. 2020.

SANTOS, Edvaldo. MOTA. Erika. LITERATURA MARGINAL: DA VIZINHANÇA AOS SLAMS DE POESIA. In: RIGO. S. Nathália (org.). Textos e contextos artísticos e literários: tradução e interpretação em Libras: volume III - 1. ed. - Petrópolis: Arara Azul, 2020.

SEGALA, R. Tradução intermodal e intersemiótica/interlingual: Português brasileiro escrito para Língua Brasileira de Sinais. (Dissertação em tradução) Centro de Comunicação e Expressão Curso de Pós-Graduação em Estudos da Tradução. UFSC, 2010.

SILVA, Elen Karla Souza; CARDOSO, Sebastião Marques. Ponciá Vicêncio: rastros de memória e ficção. Kwanissa, São Luís, n. 2, p. 55-70, jul./dez. 2018. SKLIAR, Carlos. A invenção e a exclusão da alteridade "deficiente" a partir dos significados da normalidade. Educação \& Realidade, Porto Alegre, v. 24, n. 2, p. 15-32, jul./dez. 1999

SKLIAR, Carlos. Um olhar sobre o nosso olhar acerca da surdez e das diferenças. In: SKLIAR. Carlos. (ed.). A surdez: um olhar sobre as diferenças. 6. ed. Porto Alegre: Editora Mediação, 2013. p. 07-32.

SOUZA, José Alison Lemos. Desejo e violência na literatura homoerótica. In: GOMES, Carlos Magno et al. (org.). Imaginários literários e culturais. Aracaju: Criação, 2016. p. 64-77.

SOUZA, Lívia Natalia. Uma reflexão sobre os discursos menores ou a escrevivência como narrativa subalterna. Revista Crioula, São Paulo, n. 21, p. 25-43, 2018. DOI: https://doi.org/10.11606/issn.19817169.crioula.2018.146551 


\section{_t..}

Injustiças sociais e direitos humanos nas literaturas surdas: olhares emergentes para saberes poéticos

Jonatas Rodrigues Medeiros • Silvana Aguiar dos Santos et al.

SOUZA, Nábia Araujo. Do conhecimento literário: ensaio de epistemologia interna dos estudos literários. 2006. Dissertação (Mestrado em Letras: Estudos Literários) - Faculdade de Letras, Universidade Federal de Minas Gerais, Belo Horizonte, 2006.

SOUZA, Ariel Oliveira Leite de; CORONEL, Luciana Paiva. Resistência através da escrita do testemunho em becos da memória de Conceição Evaristo. In: SEMINÁRIO CORPOS POSSÍVEIS NO BRASIL PROFUNDO - SENACORPUS, 1., 2018. Anais eletrônicos [...]. Rio Grande: Editora Realize, 2018. Disponível em:

https://www.editorarealize.com.br/editora/ebooks/senacorpus/2018/TRABA LHO_EV103_MD1_SA19_ID444_15032018164800.pdf. Acesso em: 3 nov. 2020.

SUTTON-SPENCE, Rachel. Imagens da identidade e cultura surdas na poesia em Línguas de Sinais. In: QUADROS, Ronice Müller de; VASCONCELLOS, Maria Lúcia Barbosa de. (org.). Questões teóricas das pesquisas em Línguas de Sinais. Florianópolis: UFSC, 2006. p. 329-339.

SUTTON-SPENCE, Rachel. Literatura de Língua de Sinais, Educação Surda e suas interfaces com as políticas linguísticas. Educação Unisinos, São Leopoldo, v. 24, p. $1-16, \quad 2020 . \quad$ DOI: https://doi.org/10.4013/edu.2020.241.19486

SUTTON-SPENCE. Literatura surda feita por mulheres. In: SILVA, Arlene Batista da et al. (org.). Literatura e artes, teoria e crítica feitas por mulheres. Campos dos Goytacazes: Brasil Multicultural, 2018. p. 140-164.

SUTTON-SPENCE, Rachel. Por que precisamos de poesia sinalizada em educação bilíngue. Educar em Revista, Curitiba, n. esp. 2, p. 111-128, 2014. DOI: https://doi.org/10.1590/0104-4060.37018

TERCEIRO, Francisco Martins Lopes. Deafhood: contribuições de Paddy Ladd à educação bilíngue para surdos. 2018. Dissertação (Mestrado em Educação) - Universidade Federal do Paraná, Curitiba, 2018.

WEININGER, Markus J. et al. Quando múltiplos olhares geram diferentes experiências de tradução ao português de um poema em libras: o caso de "Homenagem Santa Maria" de Godinho (2013). In: CONGRESSO NACIONAL DE PESQUISAS EM TRADUÇÃO E INTERPRETAÇÃO DE LIBRAS E LÍNGUA PORTUGUESA, 4., 2014, Florianópolis. Anais eletrônicos [...]. Florianópolis: UFSC, 2014.2 Disponível em: http://www.congressotils.com.br/anais/2014/2949.pdf. Acesso em: 28 nov. 2020. 


\section{_tı.}

Injustiças sociais e direitos humanos nas literaturas surdas: olhares emergentes para saberes poéticos

Jonatas Rodrigues Medeiros • Silvana Aguiar dos Santos et al.

\section{Publisher}

UNIVERSIDADE FEDERAL DE GOIÁS. CURSOS DE LETRAS: LIBRAS E DE LETRAS: TRADUÇÃO E INTERPRETAÇÃO EM LIBRAS/PORTUGUÊS DA FACUldade de Letras/UfG. PublicAÇÃo NO PORTAL DE PERIÓdicos UFG. AS IDEIAS EXPRESSADAS NESTE ARTIGO SÃO DE RESPONSABILIDADE DE SEUS AUTORES, NÃO REPRESENTANDO, NECESSARIAMENTE, A OPINIÃO DOS EDITORES OU DA UNIVERSIDADE. 